\title{
Biomonitoring of Phthalates, Bisphenols and Parabens in Children: Exposure, Predictors and Risk Assessment
}

\author{
Pablo Dualde ${ }^{1}$, Nuria León ${ }^{2}$, Yovana Sanchis ${ }^{2}$, Francisca Corpas-Burgos ${ }^{1}{ }^{\circledR}$, Sandra F. Fernández ${ }^{1}$, \\ Cristina S. Hernández ${ }^{1}$, Guillermo Saez ${ }^{3}{ }^{(0)}$, Erika Pérez-Zafra ${ }^{3}$, Antonio Mora-Herranz ${ }^{3}$, Olga Pardo ${ }^{1,4}$, \\ Clara Coscollà ${ }^{1}{ }^{1}$, Antonio López ${ }^{1}$, Vicent Yusà ${ }^{1,2,4, *}$ and on behalf of the BIOVAL Task Force ${ }^{\dagger}$
}

1 Foundation for the Promotion of Health and Biomedical Research of the Valencian Region, FISABIO-Public Health, Av. Catalunya, 21, 46020 Valencia, Spain; dualde_pab@gva.es (P.D.); corpas_fra@gva.es (F.C.-B.); fernandez_sanfer@gva.es (S.F.F.); acrishern@gmail.com (C.S.H.); pardo_olg@gva.es (O.P.); coscolla_cla@gva.es (C.C.); lopez_anttob@gva.es (A.L.)

2 Public Health Laboratory of Valencia, Av. Cataluña, 21, 46020 Valencia, Spain; leon_nur@gva.es (N.L.); sanchis_yov@gva.es (Y.S.)

3 Conselleria Sanitat, Universitary Hospital Doctor Peset, Av. Gaspar Aguilar, 90, 46017 Valencia, Spain; Guillermo.Saez@uv.es (G.S.); eripeza@gmail.com (E.P.-Z.); tonimora65@gmail.com (A.M.-H.)

4 Analytical Chemistry Department, University of Valencia, Edifici Jeroni Muñoz, Dr. Moliner 50, 46100 Burjassot, Spain

* Correspondence: yusa_vic@gva.es

check for updates

Citation: Dualde, P.; León, N.; Sanchis, Y.; Corpas-Burgos, F.; Fernández, S.F.; Hernández, C.S.; Saez, G.; Pérez-Zafra, E.; Mora-Herranz, A.; Pardo, O.; et al. Biomonitoring of Phthalates, Bisphenols and Parabens in Children: Exposure, Predictors and Risk Assessment. Int. J. Environ. Res. Public Health 2021, 18, 8909. https:// doi.org/10.3390/ijerph18178909

Academic Editors: Miguel Motas Guzmán and Marta Esteban López

Received: 25 June 2021

Accepted: 21 August 2021

Published: 24 August 2021

Publisher's Note: MDPI stays neutral with regard to jurisdictional claims in published maps and institutional affiliations.

Copyright: (c) 2021 by the authors. Licensee MDPI, Basel, Switzerland. This article is an open access article distributed under the terms and conditions of the Creative Commons Attribution (CC BY) license (https:// creativecommons.org/licenses/by/ $4.0 /)$. $\dagger$ Membership of the BIOVAL Task Force is provided in the Acknowledgments.

\begin{abstract}
Exposure to emerging contaminants, such as phthalates, bisphenols and parabens in children has been associated with possible neurodevelopment and endocrine alterations. In the present study, the biomonitoring of biomarkers in children (5-12 years old) from the Valencia Region (Spain) have been implemented using urines from the BIOVAL program. More than $75 \%$ of the children studied ( $n=562$ ) were internally exposed ( $>$ LOQ) to bisphenols and parabens, and the whole population assessed $(n=557)$ were exposed to at least one phthalate. The geometric means (GM) of the concentrations of bisphenol A, methyl paraben and propyl paraben were $0.9,1.4$ and $0.39 \mathrm{ng} / \mathrm{mL}$, respectively. Regarding phthalates, monoethyl phthalate GM was $55.0 \mathrm{ng} / \mathrm{mL}$ and diethyl hexyl phthalate (as the sum of five metabolites) GM was $60.6 \mathrm{ng} / \mathrm{mL}$. Despite the studied population being widely exposed, the detection frequencies and concentrations were in general lower than in previous studies involving children in Spain and in other countries in recent years. Furthermore, the risk assessment study concluded that the internal exposure to phthalates, bisphenols and parabens is lower than the guidance values established, and, therefore, a health risk derived from the exposure to these compounds in the studied population is not expected.
\end{abstract}

Keywords: biomonitoring; phthalates; bisphenols; parabens; urine; risk assessment

\section{Introduction}

The exposure to chemicals which interact with the organism is a public health issue, since it can cause alterations in the neurodevelopment or in the endocrine system [1]. During the last decades, there has been an increase in the number of studies which assess the health alterations derived from the exposure to emerging contaminants, such as bisphenols, phthalates and parabens.

Bisphenols are mainly used in food contact materials composed of polycarbonate plastics, in epoxy resins used in the internal coating of cans and in thermal papers [2]. Regarding children, the presence of bisphenols in toys can also be a source of exposure [3]. The most widely used and produced bisphenol is the bisphenol A (BPA), however, recent restrictions in its use have motivated the increase of production of BPA analogues, such as bisphenols F (BPF) and S (BPS) [4]. The exposure to bisphenols has been associated with possible alterations in the endocrine system [5]. Using toxicologic data, a temporal TDI 
(t-TDI) of $4 \mu \mathrm{g} / \mathrm{Kg}$ body weight (bw) per day has been established for the oral exposure to BPA [6].

Phthalates are plasticizers used in many applications. Long-chain phthalates, such as di-2-ethylhexyl phthalate (DEHP) and diisononyl phthalate (DiNP) are mainly used in polyvinyl chloride (PVC) materials, such as food contact materials, flooring, clothing or toys. On the other hand, short-chain phthalates, such as dimethyl phthalate (DMP), diethyl phthalate (DEP), benzylbutyl phthalate (BzBP) and diisobutyl phthalate (DiBP), are also used in personal care products, paints and in enteric-coated tablets [7]. The use of phthalates in the European Union (EU) is regulated in food contact materials [8], toys and other objects intended for child-use which can be used in the mouth [9], cosmetics [10], medicines [11] and medical devices [12]. Several studies have assessed the toxicity of phthalates in animals, and have concluded that they have negative effects on reproduction and development. Furthermore, they are considered possible endocrine disruptors in humans [13]. Regarding neurodevelopment, prenatal exposure to phthalates has been associated with negative cognitive development of children (e.g., lower intelligence quotient, attention deficit, hyperactivity and lower social communication) [14].

Parabens are chemicals used as preservatives [15]. The most widely produced parabens are methyl paraben (MP), ethyl paraben (EP), propyl paraben (PP) and butyl paraben (BP) [16]. The EU allows and regulates the use of parabens in food [17], medicines [18] and cosmetics [19]. Given the wide use of these compounds, researchers have detected levels in water [20] and other matrices [15]. Some studies with animals have correlated exposure to parabens with health effects, such as alterations in the estrogenic activity during gestation and childhood [21-23]. The EFSA has established an acceptable daily intake (ADI) for the sum of MP and EP of 0-10 $\mathrm{mg} / \mathrm{kg}$ bw per day [24].

These contaminants can be absorbed by ingestion, inhalation or dermal absorption. After entering the body, they are metabolized by phase I and/or phase II metabolites and are excreted in urine in a few hours. Bisphenols are excreted in urine mainly as conjugates [25]. Parabens have been found in urine unaltered, hydrolyzed or oxidized; furthermore, they can be conjugated with glucuronide or sulfate [26]. Regarding phthalates, they are hydrolyzed by their monoesters, and subsequently, some of them are oxidized. In urine, they can be found as free metabolites or conjugated with glucuronic acid [27].

The ongoing Human Biomonitoring for Europe (HBM4EU) project attempts to provide policy makers with comparable data on human internal exposure to chemicals and mixtures of chemicals at EU level. This project has included emerging chemicals, such as phthalates and bisphenols, in the list of priority substances which are going to be assessed within the project [28]. Unlike other countries such as Germany [29], in Spain, there is not yet a national biomonitoring program which would evaluate the exposure to phthalates, bisphenols and parabens. The BIOVAL program attempts to evaluate the exposure to these substances in children from Valencia (Spain).

The objectives of the present study are: (i) to assess the urinary levels of biomarkers of bisphenols, phthalates and parabens in the infant population of the Valencia Region (Spain); (ii) study the risk assessment in the population; and (iii) assess the predictors of these levels using food consumption and socio-demographic questionnaires.

\section{Materials and Methods}

\subsection{Study Area and Population}

The present study is included in the BIOVAL program developed in the Valencia Region. The study design was described by Perez et al., [30]. The program is focused on the biomonitoring of food contaminants in children from the Valencia Region. During 2016, a total of 666 children ( 5 to 12 years old) from 25 primary schools of Alicante, Castellón and Valencia provinces were recruited. The parents/guardians of all the participants signed an informed consent document. The program was approved by the Ethical Committees of the Valencian Research Centre for Public Health (FISABIO) of the Valencian Government (Directorate-General of Public Health). 


\subsection{Sample and Data Collection}

First-morning void (FMV) urine samples were collected during 2016 by the parents/guardians of the participants using gloves. Samples were collected in polypropylene containers with polyethylene caps. Previously to the sample collection, the container batches were tested following migration studies, in order to check the absence of phthalates or bisphenols. Samples were kept refrigerated and transported $(<24 \mathrm{~h})$ in a cooler with ice to the Biobank for Biomedical Research and Public Health of the Valencian Community (IBSP-CV Biobank) (PT13/0010/0064) integrated in the Spanish National Biobank Network and the Valencian Biobanking Network, where they were divided into aliquots and stored at $-80{ }^{\circ} \mathrm{C}$. For bisphenols, parabens and phthalate metabolite determination the aliquots were preserved in glass containers.

The participants' parents/guardians completed self-administered food consumption and socio-demographic questionnaires. The characteristics of the studied population, including the frequency of food consumption by groups in the population (grams/month), are shown in Tables 1 and S1.

Table 1. Studied population characteristics.

\begin{tabular}{|c|c|}
\hline & $n(\%)(n=562)$ \\
\hline \multicolumn{2}{|l|}{ Province } \\
\hline Alicante & $203(36.12 \%)$ \\
\hline Castellón & $122(21.71 \%)$ \\
\hline Valencia & $237(42.17 \%)$ \\
\hline \multicolumn{2}{|l|}{ Sex } \\
\hline Male & $282(50.18 \%)$ \\
\hline Female & $280(49.82 \%)$ \\
\hline Size $(\mathrm{cm})$ & $135(100-170)^{\mathrm{a}}$ \\
\hline Missing data & $17(3.02 \%)$ \\
\hline Weight (Kg) & $32(16-72)^{a}$ \\
\hline Missing data & $11(1.96 \%)$ \\
\hline BMI & $17.11(11.65-45.45)^{\mathrm{a}}$ \\
\hline Missing data & $18(3.20 \%)$ \\
\hline Age & $8(5-12)^{a}$ \\
\hline \multicolumn{2}{|l|}{ Child's country of birth } \\
\hline Spain & $552(98.75 \%)$ \\
\hline Foreign & $7(1.25 \%)$ \\
\hline Missing data & $3(0.53 \%)$ \\
\hline \multicolumn{2}{|l|}{ Parents country of birth } \\
\hline Both Spain & $488(89.38 \%)$ \\
\hline Some foreign & $58(10.62 \%)$ \\
\hline Missing data & $16(2.85 \%)$ \\
\hline Years of child's residence in the Valencia Region & $8(1-12)^{a}$ \\
\hline Missing data & $11(1.96 \%)$ \\
\hline \multicolumn{2}{|l|}{ Maximum level of education of one of the parents } \\
\hline Without studies or primary & $56(9.96 \%)$ \\
\hline Secondary & $169(30.07 \%)$ \\
\hline Superior & $337(59.96 \%)$ \\
\hline \multicolumn{2}{|l|}{ Employment situation } \\
\hline Neither parents work & $33(5.87 \%)$ \\
\hline Some of the parents work & $529(94.13 \%)$ \\
\hline
\end{tabular}


Table 1. Cont.

\begin{tabular}{|c|c|}
\hline & $n(\%)(n=562)$ \\
\hline \multicolumn{2}{|l|}{ Primary sector work } \\
\hline None & $536(95.37 \%)$ \\
\hline Someone & $26(4.63 \%)$ \\
\hline \multicolumn{2}{|l|}{ Secondary sector work } \\
\hline None & $341(60.68 \%)$ \\
\hline Someone & $221(39.32 \%)$ \\
\hline \multicolumn{2}{|l|}{ Tertiary sector work } \\
\hline None & $100(17.79 \%)$ \\
\hline Someone & $462(82.21 \%)$ \\
\hline Index MED-DQI & $4(0-10)^{a}$ \\
\hline Good $($ score $\leq 4)$ & $340(60.5 \%)$ \\
\hline Medium-good $(5 \leq$ score $\leq 7)$ & $196(34.88 \%)$ \\
\hline Medium-poor $(8 \leq$ score $\leq 10)$ & $26(4.63 \%)$ \\
\hline
\end{tabular}

\subsection{Determination of Urinary Biomarkers}

Since some participants provided low sample volumes and some of them presented with unusual levels of urinary creatinine (see the last part of Section 2.3), only 562 samples were analyzed for the determination of bisphenols and parabens, and 557 samples were analyzed for the determination of phthalate metabolites. The urinary biomarkers of bisphenols, parabens and phthalates determined in the present study are shown in Table S2. The determination of bisphenols and parabens in urine was implemented following the method described in Sanchis et al. [31]. Firstly, the enzymatic hydrolysis was implemented by adding $200 \mu \mathrm{L}$ of $1 \mathrm{M}$ ammonium acetate buffer ( $\mathrm{pH} 5.0$ ) and $10 \mu \mathrm{L}$ of $\beta$-glucuronidase/arylsulfatase to $500 \mu \mathrm{L}$ of sample. After incubation $\left(37^{\circ} \mathrm{C}, 90 \mathrm{~min}\right)$, the samples were centrifuged and the supernatant was transferred into an injection vial. The determination was implemented by high performance liquid chromatography coupled with tandem mass spectrometry, using atmospheric pressure chemical ionization in negative mode. Regarding the phthalate metabolites determination, the sample preparation was described in Dualde et al. [32]. Briefly, $500 \mu \mathrm{L}$ of urine were diluted with $660 \mu \mathrm{L}$ of ultrapure water, $200 \mu \mathrm{L}$ of $1 \mathrm{M}$ ammonium acetate buffer and $10 \mu \mathrm{L}$ of enzyme $\beta$-glucuronidase (from E. coli K12). Then, the samples were incubated $\left(90 \mathrm{~min}, 37^{\circ} \mathrm{C}\right)$ and centrifuged. In total, $200 \mu \mathrm{L}$ of the supernatant were transferred to the injection vial, and $10 \mu \mathrm{L}$ were injected in the liquid chromatography coupled with a tandem mass spectrometry (LC-MS/MS) system, using electrospray ionization in negative mode.

Regarding quality assurance and quality control, samples were analyzed under quality system protocols following the ISO/IEC/EN 17,025 requirements. The limit of quantification (LOQ) was defined as the lowest level at which an analyte can be determined with acceptable recovery and precision. The procedural LOQ for each compound is presented in Table 2. Quality control samples to check the performance of the method were used in each batch, including reagent blanks, matrix blanks and spiked blank samples according to the SANTE/11813/2017 guideline [33]. The following performance criteria were used: recoveries within $70-120 \%$ and repeatability RSD $\leq 20 \%$. Regarding linearity, $\mathrm{R}^{2}>0.98$ was obtained. Furthermore, the laboratory participated in the G-EQUAS inter-comparison program, round 62, in 2018, for the available urinary phthalate metabolites (MEHP, MECPP, MEHHP, MEOHP, MBzP, MnBP and MiBP) at two concentration levels, and in the ICIEQUAS inter-comparison program, round 03, in 2019, for the available urinary phthalate metabolites (MEP, MEHP, MECPP, MEHHP, MEOHP, MBzP, MnBP, MiBP, MCHP and MOP) at two concentration levels, to guarantee the reliability of the results. The laboratory successfully fulfilled the requirements for all the phthalate metabolites evaluated in both programs. 
Table 2. Levels of contaminant biomarkers in urine samples.

\begin{tabular}{|c|c|c|c|c|c|c|c|c|c|c|c|}
\hline Analyte & $n$ & $\begin{array}{l}\text { DF } \\
(\%)\end{array}$ & $\begin{array}{l}\text { LOQ } \\
\mathrm{ng} / \mathrm{mL}\end{array}$ & $\begin{array}{l}\text { Minimum } \\
\text { ng/mL ( } \mu \mathrm{g} / \mathrm{g} \\
\text { Creat) }\end{array}$ & $\begin{array}{c}\text { P25 ng/mL } \\
(\mu g / g \text { Creat) }\end{array}$ & $\begin{array}{l}\text { GM ng/mL } \\
(\mu \mathrm{g} / \mathrm{g} \text { Creat })\end{array}$ & $\begin{array}{c}\text { Median } \\
\text { ng/mL }(\mu \mathrm{g} / \mathrm{g} \\
\text { Creat })\end{array}$ & $\begin{array}{l}\text { P75 ng/mL } \\
\text { ( } \mu \mathrm{g} / \mathrm{g} \text { Creat) }\end{array}$ & $\begin{array}{l}\text { P95 ng/mL } \\
(\mu \mathrm{g} / \mathrm{g} \text { Creat) }\end{array}$ & $\begin{array}{l}\text { Maximum ng/mL } \\
(\mu \mathrm{g} / \mathrm{g} \text { Creat })\end{array}$ & $\begin{array}{l}\text { Std dev ng/mL } \\
(\mu \mathrm{g} / \mathrm{g} \text { Creat })\end{array}$ \\
\hline BPA & 562 & 63.3 & 0.2 & $<\mathrm{LOQ}$ & $<\mathrm{LOQ}$ & $0.90(0.92)$ & $1.6(1.8)$ & $10.4(9.9)$ & $85.2(95.2)$ & $6246.2(6277.6)$ & $294.4(299.3)$ \\
\hline BPS & 562 & 28.6 & 0.2 & $<\mathrm{LOQ}$ & $<\mathrm{LOQ}$ & $<\mathrm{LOQ}$ & $<\mathrm{LOQ}$ & $0.30(0.31)$ & $6.8(6.1)$ & $153.5(96.5)$ & $10.0(7.8)$ \\
\hline EBisphenols & 562 & 75.6 & - & - & - & $2.3(2.3)$ & $3.3(3.6)$ & $13.4(13.7)$ & $154.2(154.0)$ & $6246.2(6277.6)$ & $337.7(377.6)$ \\
\hline MP & 562 & 62.3 & 0.2 & $<\mathrm{LOQ}$ & $<\mathrm{LOQ}$ & $1.4(1.4)$ & $2.4(2.5)$ & $61.7(60.6)$ & $541.4(574.4)$ & $23210.0(27598.1)$ & $1100.0(1253.5)$ \\
\hline $\mathrm{EP}$ & 562 & 48.4 & 0.2 & $<\mathrm{LOQ}$ & $<\mathrm{LOQ}$ & $<$ LOQ & $<$ LOQ & $2.0(2.2)$ & $18.0(21.0)$ & 910.7 (1081.6) & $51.6(58.6)$ \\
\hline PP & 562 & 59.6 & 0.2 & $<\mathrm{LOQ}$ & $<\mathrm{LOQ}$ & $0.39(0.40)$ & $0.40(0.41)$ & $2.3(2.4)$ & $61.3(61.3)$ & $378.7(527.0)$ & $43.7(44.5)$ \\
\hline $\mathrm{BP}$ & 562 & 21.5 & 0.2 & $<\mathrm{LOQ}$ & $<\mathrm{LOQ}$ & $<$ LOQ & $<\mathrm{LOQ}$ & $<$ LOQ & $7.3(9.1)$ & $475.2(568.5)$ & $56.6(70.2)$ \\
\hline$\sum$ Parabens & 562 & 88.1 & - & - & - & $9.4(9.5)$ & $8.7(8.5)$ & $80.5(80.5)$ & 833.7 (881.6) & $23498.0(27940.6)$ & $1124.4(1282.3)$ \\
\hline MEP & 557 & 99.8 & 2 & $<$ LOQ & $26.9(26.7)$ & $55.0(55.9)$ & $51.1(53.2)$ & $100.6(105.1)$ & $498.0(405.4)$ & $8273.0(13,343.5)$ & $438.5(612.0)$ \\
\hline MiBP & 557 & 98.6 & 2 & $<\mathrm{LOQ}$ & $9.7(10.7)$ & $18.4(18.7)$ & $18.4(17.6)$ & $31.6(32.0)$ & $83.2(85.4)$ & $1039.2(659.8)$ & $56.0(44.2)$ \\
\hline MnBP & 557 & 99.6 & 0.5 & $<\mathrm{LOQ}$ & $8.2(8.7)$ & $14.0(14.2)$ & $13.8(13.6)$ & $23.7(21.6)$ & $51.5(58.6)$ & $309.4(325.1)$ & $30.9(31.8)$ \\
\hline MBzP & 557 & 88.2 & 1 & $<\mathrm{LOQ}$ & $1.5(1.5)$ & $3.0(3.0)$ & $2.8(2.9)$ & $5.6(5.4)$ & $17.8(19.5)$ & $110.7(89.4)$ & $11.0(9.6)$ \\
\hline 2cxMMHP & 557 & 77.9 & 2 & $<\mathrm{LOQ}$ & $2.2(2.4)$ & $4.0(4.1)$ & $4.0(4.1)$ & $7.1(6.8)$ & $18.5(19.5)$ & $93.3(171.7)$ & $9.0(11.1)$ \\
\hline MEOHP & 555 & 100 & 0.5 & $0.7(1 . \hat{1})$ & $5.2(5.4)$ & $9.1(9.2)$ & $9.3(9.2)$ & $15.9(15.0)$ & $37.9(34.2)$ & $267.2(352.4)$ & $17.3(23.0)$ \\
\hline МЕСРP & 557 & 100 & 1 & $1.8(2.1)$ & $15.5(15.6)$ & $27.0(27.5)$ & $27.9(29.1)$ & $50.6(45.9)$ & $101.0(90.5)$ & $480.7(890.3)$ & $39.2(50.7)$ \\
\hline MEHP & 557 & 84.6 & 1 & $<\mathrm{LOQ}$ & $1.8(1.7)$ & $3.6(3.6)$ & $3.7(3.8)$ & $7.7(7.5)$ & $24.0(25.2)$ & 99.7 (117.2) & $9.4(11.3)$ \\
\hline $\begin{array}{c}\mathrm{DEHP}\left(\sum \mathrm{MEHHP}+\right. \\
\mathrm{MEOHP})\end{array}$ & 555 & 100 & - & - & $12.9(13.7)$ & $21.6(21.9)$ & $22.4(29.1)$ & $34.6(33.1)$ & $86.9(78.6)$ & $459.3(980.5)$ & $37.6(54.2)$ \\
\hline DEHP $\left(\sum 5 \text { metabolites }\right)^{a}$ & 555 & 100 & - & - & $35.1(37.5)$ & $60.6(61.6)$ & $62.1(61.8)$ & $101.8(97.6)$ & $214.5(198.8)$ & $1044.8(2159.7)$ & $84.6(117.3)$ \\
\hline$\sum$ Phthalates & 555 & 100 & - & - & $113.9(115.4)$ & $185.9(188.9)$ & $176.2(176.8)$ & $289.0(285.7)$ & $703.2(673.4)$ & $8356.8(13,478.7)$ & $463.8(635.7)$ \\
\hline
\end{tabular}

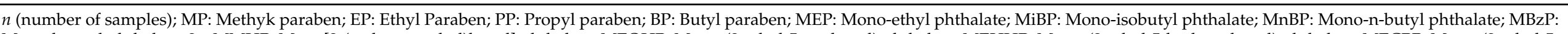

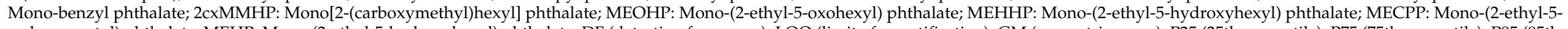

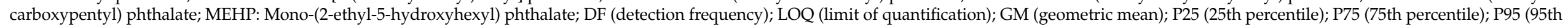

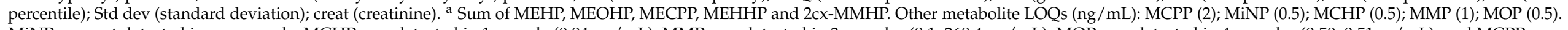

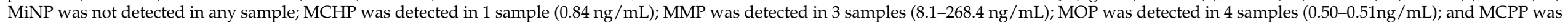
detected in 17 samples $(2.5-47.2 \mathrm{ng} / \mathrm{mL}$ ). Limit of detection (LOD) was calculated as 1/3 LOQ. 
The creatinine determination was implemented at the University Hospital Doctor Peset (Valencia, Spain) using Jaffé's reaction. The samples with urinary creatinine outside of the normal range $(0.3-3 \mathrm{~g} / \mathrm{L})$ [34] were excluded $(n=7)$.

\subsection{Statistical Analysis}

Statistical analysis was performed using R software (version 3.5.2). Urinary biomarker levels below limit of quantification (LOQ) were estimated following the maximum likelihood estimation method described in [35]. This method assumes that the data are distributed according to a certain parametric distribution, and estimates the parameters of this distribution by maximizing the probability of obtaining the observed sample. A log-normal distribution was assumed for the biomarker levels in urine.

First, a descriptive analysis of all the study variables was performed. Qualitative variables were described by absolute frequencies and percentages. Quantitative variables were summarized by their median and range. Additionally, biomarkers levels in urine were summarized by calculating the minimum, 25th, 50th, 75th and 95th percentiles, arithmetic and geometric means, maximum and standard deviation (Table 2).

Multiple logistic regression models were built to study associations between the presence of bisphenols and parabens in urine, and the socio-demographic and dietetic characteristics of the participants. The presence of phenols in urine (levels above the limit of detection) was considered a dependent variable in the models. The independent variables were sex, BMI, parent's country of birth, maximum level of education of one of the parents, employment situation, MED-DQI index and food consumption. In order to directly compare the magnitude of regression coefficients, the numerical explanatory variables were centered and divided by twice their standard deviation, as proposed by Gelman [36]. The models were built following a forward variable selection procedure based on the Akaike Information Criterion (AIC) [37]. The quality of the fit of models was assessed using the Hosmer-Lemeshow test, exploring the model residuals (verifying that there are no observations with large residues) and calculating the area under the receiver operator characteristic (ROC) curve.

Multiple robust linear regression models were built to assess the relationship between the concentration of each phthalate in urine, and socio-demographic and dietary variables. The logarithmic transformation of phthalate levels in urine was considered to obtain the normality of the response variables (see Figure S1). Robust regression was considered as an alternative to ordinary least squares estimation methods (OLS), given the presence of some outlier values in phthalate levels. In order to directly compare the magnitude of regression coefficients, the numerical explanatory variables were centered and divided by twice their standard deviation, as proposed by Gelman [36]. The models were built following a backward variable selection procedure based on the robust final prediction error [38]. Confidence intervals at $95 \%$ significance were calculated for the model coefficients, to indicate the precision and uncertainty of the sample statistical estimates.

\subsection{Risk Assessment}

The urinary levels of BPA and phthalate metabolites were compared with their reference HBMs and / or biomonitoring equivalent (BEs) values (Table S3 [39]).

In the present study, a conservative scenario was chosen. If there was more than one $\mathrm{BE}$ for each biomarker, the lowest $\mathrm{BE}$ was selected as the guidance value. The hazard quotient (HQ) was calculated as the quotient between P95 of the biomarker levels in the population with the above-mentioned BEs or HBM-I values. See Equation (1):

$$
\text { HQ }=\text { P95/Guidance value }
$$

The HQs were used to evaluate the health risk of the child population. If a biomarker concentration is below the guidance value $(\mathrm{HQ}<1)$, a health risk is not expected. Nevertheless, a health risk cannot be discarded if the $\mathrm{HQ}>1$. 
Regarding paraben levels, there were no guidance values for these compounds in urine. Therefore, the estimated daily intake (EDI) was calculated in order to implement the risk assessment by using reverse dosimetry [40]. See Equation (2):

$$
\left.\operatorname{EDI}(\mathrm{mg} / \mathrm{kg} \text { bw day })=\left(\mathrm{C}(\mathrm{mg} / \mathrm{L}) \mathrm{V}_{\text {urine }}(\mathrm{L} / \text { day })\right) / \mathrm{F} \mathrm{BW}(\mathrm{kg})\right)
$$

where $\mathrm{C}$ is the paraben concentration, $\mathrm{V}_{\text {urine }}$ is the urinary volume excreted per day, $\mathrm{F}$ is the compound's urinary excretion factor and BW is the body weight. Since a conservative scenario was followed, C was the 95th percentile (P95) of the paraben levels. The total volume of urine for children (6-12 years old) was $0.66 \mathrm{~L}$ per day according to Remer et al. [41]. There was no data available for the urinary excretion factor of parabens, and consequently a conservative F of 0.25 was selected. The median body weight of the participants was $32 \mathrm{~kg}$ (Table 1). The risk assessment was estimated by comparing the EDI calculated with the acceptable daily intake (ADI) of $0-10 \mathrm{mg} / \mathrm{kg}$ bw/day established by EFSA [24]. Consequently, the risk assessment for the sum of MP and EP was implemented using the HQ according to Equation (3):

$$
\mathrm{HQ}=(\Sigma \mathrm{EDI} \text { calculated }) /(\mathrm{ADI})
$$

\section{Results}

\subsection{Biomarker Urinary Levels}

The levels of urinary biomarkers of bisphenols, parabens and phthalates in the population studied are shown in Table 2. In total, $75 \%$ of children had detectable levels of at least one bisphenol, with BPA being the most widely detected (DF 63\%), and BPS levels were detected in almost $30 \%$ of the samples while BPF presented a DF of $11 \%$. Regarding parabens, $88 \%$ of the children had detectable levels of one of the four parabens studied, with MP and PP being the ones which shown the highest DF (62.3 and 59.6\%, respectively). In the case of phthalates, all participants had quantifiable levels of at least one biomarker. Nine out of the fourteen phthalate metabolites studied presented DFs $>77 \%$. The rest of phthalate metabolites were only detected in a few samples (DF $<5 \%$ ).

Regarding the measured concentrations, in case of bisphenols, BPA showed the highest geometric mean (GM) $(0.9 \mathrm{ng} / \mathrm{mL})$, while the levels of BPF and BPS were much lower $(\mathrm{GMs}<0.2 \mathrm{ng} / \mathrm{mL})$. The paraben which showed the highest levels was MP (GM $1.4 \mathrm{ng} / \mathrm{mL}$ ), followed by PP $(\mathrm{GM}=0.39 \mathrm{ng} / \mathrm{mL})$. BP showed the lowest concentrations. In the case of phthalates, the metabolite which presented the highest concentrations was MEP, the biomarker of DEP. However, DEHP, as the sum of five metabolites, was the phthalate which presented the highest levels of metabolites in urine $(\mathrm{GM}=60.6 \mathrm{ng} / \mathrm{mL})$.

\subsection{Determinants}

The determinants of the biomarkers which presented DFs $>40 \%$ were assessed. Table 3 shows the multiple logistic regression models for the presence of BPA, MP, EP and PP in urine. The consumption of eggs, canned fish and processed fish was negatively associated with the levels of BPA in urine, however, the consumption of white fish and drinks were positively associated with BPA concentrations. 
Table 3. Results of the multiple logistic regression model for presence of BPA, MP, EP and PP in urine (levels $\geq$ LOQ).

\begin{tabular}{|c|c|c|c|c|}
\hline Variable & $\begin{array}{l}\text { Standardized Coefficients } \\
(95 \% \mathrm{CI})\end{array}$ & Standard Error & $p$-Value & $\begin{array}{l}\text { Odd Ratio } \\
(95 \% \text { CI })\end{array}$ \\
\hline \multicolumn{5}{|l|}{ BPA } \\
\hline Intercept & $\begin{array}{c}0.5621 \\
(0.3819-0.7457)\end{array}$ & 0.0927 & $<0.0001^{*}$ & - \\
\hline Canned fish & $\begin{array}{c}-0.611 \\
(-1.0895--0.1863)\end{array}$ & 0.2332 & 0.0088 * & $\begin{array}{c}0.5428 \\
(0.3364-0.83)\end{array}$ \\
\hline Processed fish & $\begin{array}{c}-0.3781 \\
(-0.7703--0.0167)\end{array}$ & 0.1897 & 0.0463 * & $\begin{array}{c}0.6851 \\
(0.4629-0.9835)\end{array}$ \\
\hline White fish & $\begin{array}{c}0.3996 \\
(0.0228-0.7886)\end{array}$ & 0.1949 & 0.0404 * & $\begin{array}{c}1.4912 \\
(1.023-2.2002)\end{array}$ \\
\hline MED-DQI index & $\begin{array}{c}-0.2953 \\
(-0.6718-0.0778)\end{array}$ & 0.1909 & 0.1219 & $\begin{array}{c}0.7443 \\
(0.5108-1.0809)\end{array}$ \\
\hline Drinks & $\begin{array}{c}0.4916 \\
(0.054-1.0248)\end{array}$ & 0.2462 & $0.0459 *$ & $\begin{array}{c}1.6349 \\
(1.0555-2.7865)\end{array}$ \\
\hline Eggs & $\begin{array}{c}-0.2042 \\
(-0.3918--0.0203)\end{array}$ & 0.0944 & $0.0306 *$ & $\begin{array}{c}0.8153 \\
(0.6758-0.9799)\end{array}$ \\
\hline \multicolumn{5}{|l|}{ MP } \\
\hline Intercept & $\begin{array}{c}1.0693 \\
(0.4807-1.7133)\end{array}$ & 0.3121 & 0.0006 * & - \\
\hline Eggs & $\begin{array}{c}0.2288 \\
(-0.1292-0.5917) \\
\end{array}$ & 0.1834 & 0.2122 & $1.2571(0.8788-1.807)$ \\
\hline Drinks & $\begin{array}{c}-0.1802 \\
(-0.5406-0.1711)\end{array}$ & 0.1784 & 0.3125 & $0.8351(0.5824-1.1866)$ \\
\hline $\begin{array}{l}\text { Maximum level of education of } \\
\text { one of the parents: secondary }\end{array}$ & $\begin{array}{c}-0.3742 \\
(-1.0886-0.2996)\end{array}$ & 0.3522 & 0.2880 & $0.6879(0.3367-1.3493)$ \\
\hline $\begin{array}{l}\text { Maximum level of education } \\
\text { of one of the parents: superior }\end{array}$ & $\begin{array}{c}-0.6319 \\
(-1.3087--0.0036)\end{array}$ & 0.3308 & 0.0561 & $0.5316(0.2702-0.9964)$ \\
\hline $\begin{array}{l}\text { Parents country of birth: some } \\
\text { foreign }\end{array}$ & $\begin{array}{c}-0.5752 \\
(-1.1375-0.0133)\end{array}$ & 0.2856 & 0.0440 * & $0.5626(0.3206-0.9868)$ \\
\hline \multicolumn{5}{|l|}{ EP } \\
\hline Intercept & $\begin{array}{c}-0.7776 \\
(-1.5772--0.0472)\end{array}$ & 0.3857 & 0.0438 * & - \\
\hline Fishing products & $\begin{array}{c}0.1886 \\
(-0.2073-0.5905)\end{array}$ & 0.2027 & 0.3522 & $1.2076(0.8128-1.805)$ \\
\hline Bivalve molluscs & $\begin{array}{c}-0.1624 \\
(-0.6232-0.2355)\end{array}$ & 0.2142 & 0.4485 & $0.8501(0.5362-1.2655)$ \\
\hline $\begin{array}{l}\text { Employment situation: some } \\
\text { of the parents work }\end{array}$ & $\begin{array}{c}0.7389 \\
(-0.0129-1.5565)\end{array}$ & 0.396 & 0.0620 & $2.0936(0.9871-4.742)$ \\
\hline MED-DQI index & $\begin{array}{c}0.4045 \\
(0.0521-0.7627)\end{array}$ & 0.181 & 0.0254 * & $1.4986(1.0535-2.1442)$ \\
\hline
\end{tabular}


Table 3. Cont.

\begin{tabular}{|c|c|c|c|c|}
\hline Variable & $\begin{array}{l}\text { Standardized Coefficients } \\
\qquad(95 \% \mathrm{CI})\end{array}$ & Standard Error & $p$-Value & $\begin{array}{l}\text { Odd Ratio } \\
(95 \% \mathrm{CI})\end{array}$ \\
\hline \multicolumn{5}{|l|}{$\mathbf{P P}$} \\
\hline Intercept & $\begin{array}{c}0.2386 \\
(-0.011-0.4905)\end{array}$ & 0.1278 & 0.0619 & - \\
\hline Sex: female & $\begin{array}{c}0.4281 \\
(0.079-0.7796)\end{array}$ & 0.1786 & 0.0165 * & $\begin{array}{c}1.5343 \\
(1.0822-2.1805)\end{array}$ \\
\hline $\begin{array}{l}\text { Parents country of birth: some } \\
\text { foreign }\end{array}$ & $\begin{array}{c}-0.746 \\
(-1.325--0.1781)\end{array}$ & 0.2913 & 0.0104 * & $\begin{array}{c}0.4742 \\
(0.2658-0.8368)\end{array}$ \\
\hline Nuts & $\begin{array}{c}-0.2255 \\
(-0.5896-0.1213) \\
\end{array}$ & 0.1787 & 0.2069 & $\begin{array}{c}0.7981 \\
(0.5545-1.1289) \\
\end{array}$ \\
\hline White fish & $\begin{array}{c}0.2829 \\
(-0.0703-0.6443)\end{array}$ & 0.1819 & 0.1198 & $\begin{array}{c}1.327 \\
(0.9321-1.9047)\end{array}$ \\
\hline Creatinine & $\begin{array}{c}0.2978 \\
(-0.059-0.6639)\end{array}$ & 0.184 & 0.1055 & $\begin{array}{c}1.3469 \\
(0.9427-1.9423)\end{array}$ \\
\hline
\end{tabular}

Regarding parabens, participants who had foreign fathers showed lower levels of MP and PP. Furthermore, female children presented with significatively higher levels of PP, and a fewer adhesion to the Mediterranean diet quality index was associated with higher EP levels.

Table 4 shows the robust multiple linear regression model for the logarithmically adjusted levels of phthalate metabolites. Regarding the frequency of food consumption, a higher consumption of molluscs was associated with higher levels of a BzBP metabolite (MBzP) and two DEHP metabolites (2cx-MMHP and MEHP). The consumption of small blue fish was positively associated with MEP levels, however, it was negatively associated with MEOHP levels. Furthermore, the consumption of eggs was negatively associated with the levels of MnBP, and a higher ingestion of drinks was associated with higher levels of MEP and a low adhesion to the Mediterranean diet quality index was associated with higher MEP levels. Regarding socio-demographic variables, the children with foreign parents presented higher levels of MnBP, the children with both parents unemployed had lower levels of MBzP, and the girls presented lower levels of MEHP. Since only $11 \%$ of the participants had foreign parents and only $6 \%$ of children had both parents unemployed, these associations could be inconsistent.

Table 4. Results of the robust multiple linear regression model for the logarithmically adjusted levels of phthalate metabolites.

\begin{tabular}{|c|c|c|c|}
\hline Variable & Standardized Coefficients (95\% CI) & Standard Error & $p$-Value \\
\hline \multicolumn{4}{|c|}{ MnBP } \\
\hline Intercept & $2.7426(2.4768-3.0084)$ & 0.1356 & $<0.0001$ * \\
\hline Employment situation: some of the parents work & $-0.1904(-0.4626-0.0818)$ & 0.1389 & 0.1709 \\
\hline Fishing products & $-0.0825(-0.2316-0.0666)$ & 0.0761 & 0.2786 \\
\hline Nuts & $-0.056(-0.1902-0.0782)$ & 0.0685 & 0.4142 \\
\hline Legumes, potatoes and cereals & $0.1008(-0.0323-0.2339)$ & 0.0679 & 0.1386 \\
\hline Miscellany & $-0.147(-0.2761--0.0179)$ & 0.0659 & $0.0261 *$ \\
\hline Molluscs & $0.1121(-0.032-0.2562)$ & 0.0735 & 0.1278 \\
\hline Creatinine & $0.5694(0.4399-0.6989)$ & 0.0660 & $<0.0001$ * \\
\hline Parents country of birth: foreign & $0.2621(0.0499-0.4743)$ & 0.1083 & $0.0158 *$ \\
\hline
\end{tabular}


Table 4. Cont.

\begin{tabular}{|c|c|c|c|}
\hline Variable & Standardized Coefficients (95\% CI) & Standard Error & $p$-Value \\
\hline \multicolumn{4}{|c|}{ MEP } \\
\hline Intercept & $4.3685(4.0006-4.7364)$ & 0.1877 & $<0.0001 *$ \\
\hline Employment situation: some of the parents work & $-0.4829(-0.8617--0.1041)$ & 0.1933 & 0.0128 * \\
\hline Vegetables and fruits & $-0.1712(-0.355-0.0126)$ & 0.0938 & 0.0685 \\
\hline Drinks & $0.2734(0.0893-0.4575)$ & 0.0939 & 0.0038 * \\
\hline White fish & $-0.1469(-0.3335-0.0397)$ & 0.0952 & 0.1234 \\
\hline Small blue fish & $0.2173(0.0325-0.4021)$ & 0.0943 & $0.0215 *$ \\
\hline Creatinine & $0.2868(0.1104-0.4632)$ & 0.0900 & 0.0015 * \\
\hline Index MED-DQI & $0.1944(0.0116-0.3772)$ & 0.0932 & 0.0376 * \\
\hline \multicolumn{4}{|c|}{ MBzP } \\
\hline Intercept & $0.6615(0.2973-1.0257)$ & 0.1858 & 0.0004 * \\
\hline Sex: female & $-0.1634(-0.328-0.0012)$ & 0.084 & 0.0521 \\
\hline Employment situation: some of the parents work & $0.4865(0.1252-0.8478)$ & 0.1843 & $0.0086^{*}$ \\
\hline Drinks & $-0.1339(-0.3112-0.0434)$ & 0.0905 & 0.1393 \\
\hline Molluscs & $0.1739(0.0106-0.3372)$ & 0.0833 & $0.0374 *$ \\
\hline Creatinine & $0.5207(0.3569-0.6845)$ & 0.0836 & $<0.0001$ * \\
\hline \multicolumn{4}{|c|}{ 2-cx-MMHP } \\
\hline Intercept & $1.3302(1.2469-1.4135)$ & 0.0425 & $<0.0001 *$ \\
\hline Small blue fish & $-0.1193(-0.2777-0.0391)$ & 0.0808 & 0.1404 \\
\hline Molluscs & $0.2479(0.0815-0.4143)$ & 0.0849 & 0.0037 * \\
\hline Creatinine & $0.6442(0.4878-0.8006)$ & 0.0798 & $<0.0001$ * \\
\hline Parents country of birth: foreign & $0.2467(-0.0081-0.5015)$ & 0.1300 & 0.0583 \\
\hline \multicolumn{4}{|c|}{ МЕОНР } \\
\hline Intercept & $2.167(2.0976-2.2364)$ & 0.0354 & $<0.0001 *$ \\
\hline Small blue fish & $-0.1423(-0.2841--5 e-04)$ & 0.0724 & 0.0498 * \\
\hline Creatinine & $0.6157(0.4763-0.7551)$ & 0.0711 & $<0.0001$ * \\
\hline \multicolumn{4}{|c|}{ MEHHP } \\
\hline Intercept & $2.3829(2.3098-2.456)$ & 0.0373 & $<0.0001 *$ \\
\hline Small blue fish & $-0.106(-0.2453-0.0333)$ & 0.0711 & 0.1365 \\
\hline Creatinine & $0.6033(0.464-0.7426)$ & 0.071 & $<0.0001$ * \\
\hline Parents country of birth: foreign & $0.1711(-0.0516-0.3938)$ & 0.1136 & 0.1326 \\
\hline \multicolumn{4}{|l|}{ MECPP } \\
\hline Intercept & 3.2709 (3.1991-3.3427) & 0.0366 & $<0.0001$ * \\
\hline Canned molluscs & $-0.142(-0.3147-0.0307)$ & 0.0881 & 0.1078 \\
\hline Canned fish & $0.0925(-0.1038-0.2888)$ & 0.1001 & 0.3562 \\
\hline Creatinine & $0.6402(0.4964-0.784)$ & 0.0734 & $<0.0001$ * \\
\hline \multicolumn{4}{|c|}{ MEHP } \\
\hline Intercept & $1.7405(1.2842-2.1968)$ & 0.2328 & $<0.0001$ * \\
\hline Sex: female & $-0.2312(-0.4412--0.0212)$ & 0.1072 & 0.0314 * \\
\hline Employment situation: some of the parents work & $-0.3765(-0.8282-0.0752)$ & 0.2304 & 0.1029 \\
\hline Fish & $-0.2053(-0.4223-0.0117)$ & 0.1107 & 0.0643 \\
\hline Molluscs & $0.2233(0.0086-0.438)$ & 0.1095 & $0.0420 *$ \\
\hline Canned fish & $0.191(-0.0181-0.4001)$ & 0.1067 & 0.0740 \\
\hline Creatinine & $0.6193(0.4045-0.8341)$ & 0.1096 & $<0.0001$ * \\
\hline \multicolumn{4}{|c|}{ MiBP } \\
\hline Intercept & $3.22(2.8943-3.5457)$ & 0.1662 & $<0.0001$ * \\
\hline Employment situation: some of the parents work & $-0.3651(-0.6971--0.0331)$ & 0.1694 & $0.0316^{*}$ \\
\hline Eggs & $-0.1845(-0.3372--0.0318)$ & 0.0779 & $0.0182 *$ \\
\hline Water & $-0.1395(-0.2913-0.0123)$ & 0.0774 & 0.0722 \\
\hline Creatinine & $0.5634(0.4112-0.7156)$ & 0.0776 & $<0.0001$ * \\
\hline Parents country of birth: foreign & $0.211(-0.0282-0.4502)$ & 0.122 & 0.0845 \\
\hline
\end{tabular}




\subsection{Risk Assessment}

Figure 1 shows the HQs for all compounds assessed using the P95 values. None of the contaminants studied had HQs higher than one, therefore a health risk is not expected. The phthalates DEHP (as the sum of five metabolites in $\mathrm{ng} / \mathrm{mL}$ ) and DnBP (as MnBP in $\mathrm{ng} / \mathrm{mL}$ ) showed the highest HQs (0.50 and 0.26, respectively). The lowest HQs were for $\sum \mathrm{MP}+\mathrm{EP}$ (in $\mathrm{mg} / \mathrm{kg}$ bw day) and BzBP (as MBzP in $\mathrm{ng} / \mathrm{mL}$ ) (0.05 and 0.047, respectively).

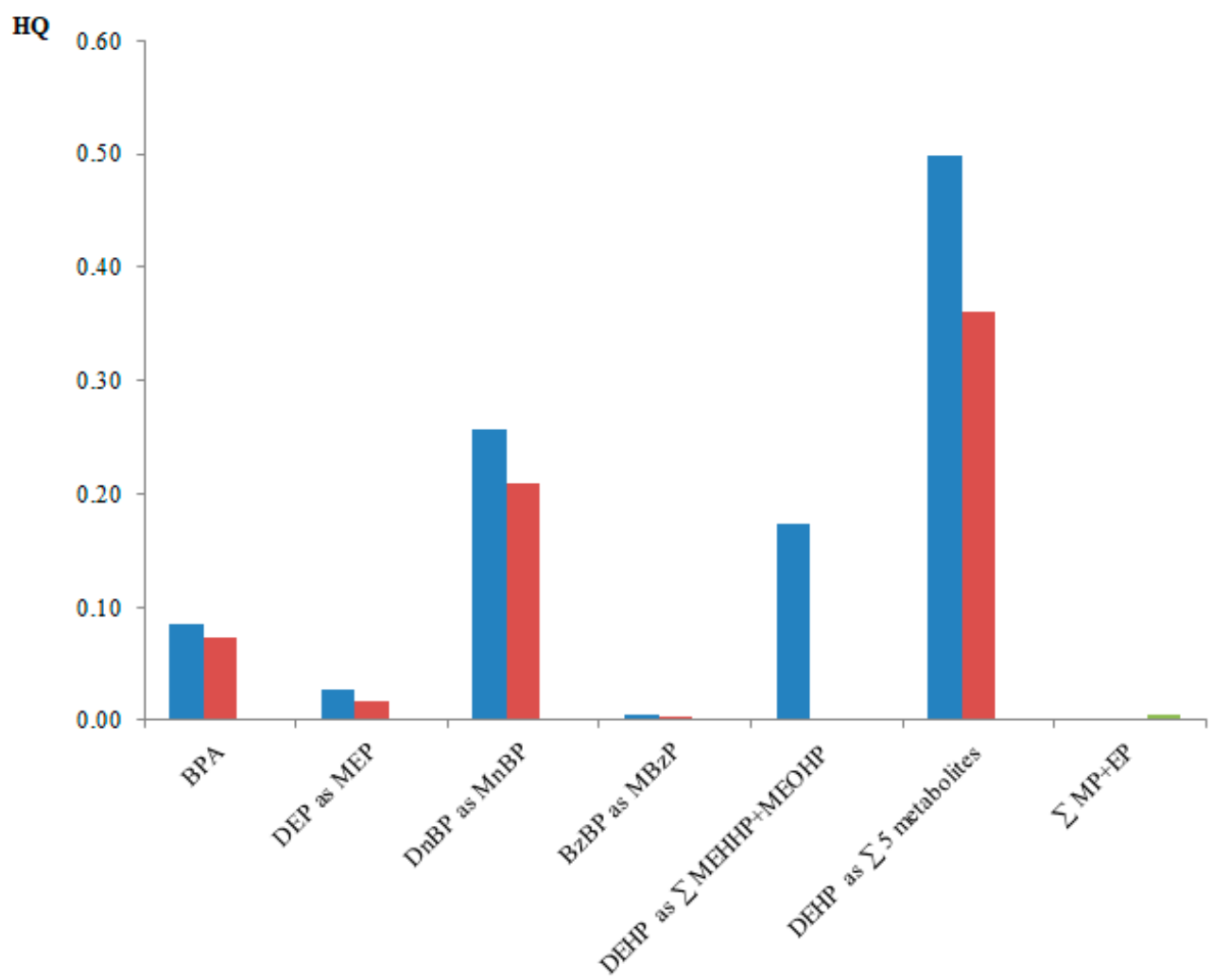

Figure 1. HQs calculated in the present study. Blue columns: HQs calculated using ng/mL; red columns: HQs calculated using $\mu \mathrm{g} / \mathrm{g}$ creatinine; green columns: for parabens only, HQ calculated using EDI and ADI.

\section{Discussion}

The assessment of children's internal exposure to bisphenols, parabens and phthalates through urine analysis revealed the wide exposure to these compounds in the Valencia Region (Spain). In total, 75\% of children had been exposed to at least one bisphenol, $88 \%$ to at least one paraben and 100\% to at least one phthalate. Previously, other studies worldwide have assessed the exposure of children to these compounds. Table 5 shows the levels of these three groups of substances in the urine of children in international studies since 2016, and with a number of participants higher than 200.

BPA was the most frequently detected bisphenol in all studies, followed by BPS and BPF, except in the study developed in Hokkaido (Japan) whereby BPF was slightly more frequently detected than BPS. BPA also showed the highest concentrations in all studies. In comparison with the Valencian children, the study developed in Canada showed similar concentrations (GMs 0.90 and $0.97 \mathrm{ng} / \mathrm{mL}$, for the present study and the Canadian study, respectively). On the contrary, the two studies developed in China (in Jiangsu and in Guangzhou) and the one developed in USA showed higher levels. However, the studies developed in Hokkaido and South Korea showed lower levels than in the present study. 
Table 5. Urinary levels of bisphenols, parabens and phthalates in children in large studies $(n>200)$ with samples collected since 2016.

\begin{tabular}{|c|c|c|c|c|c|c|c|c|c|c|}
\hline Analyte & Country (City or Region) & Year SAMPLING & $\begin{array}{c}\text { Age } \\
\text { (Years) }\end{array}$ & $\begin{array}{c}\text { Sample } \\
\text { Size }\end{array}$ & $\begin{array}{c}\text { LOQ } \\
\text { (ng/mL) }\end{array}$ & DF\% & $\begin{array}{l}\text { GM ng/mL } \\
\text { ( } \mu \mathrm{g} / \mathrm{g} \text { Creat) }\end{array}$ & $\begin{array}{c}\text { Median ng/mL } \\
(\mu \mathrm{g} / \mathrm{g} \text { Creat })\end{array}$ & $\begin{array}{l}\text { P95 ng/mL } \\
\text { ( } \mu g / g \text { Creat) }\end{array}$ & Reference \\
\hline \multirow{6}{*}{ BPA } & Canada & $2016-2017$ & $6-11$ & 516 & $0.32 *$ & 88.6 & 0.97 & 0.94 & 5.5 & {$[42]$} \\
\hline & China (Jiangsu) & 2016-2017 (approx) ** & 7 & 412 & $0.01 *$ & 99.3 & 4.66 & 2.41 & 287 & [43] \\
\hline & USA & 2013-2016 & $6-11$ & 965 & 0.2 & - & 1.28 & - & - & [45] \\
\hline & South Korea & 2017-2018 & $7-12$ & 286 & $0.24^{* * *}$ & 85 & 0.7 & 0.53 & 4.9 & [46] \\
\hline & China (Guangzhou) & 2014-2017 & $6-12$ & 250 & $0.25^{* * *}$ & 87.2 & 1.7 & 2.24 & 14.4 & [47] \\
\hline & Spain (Valencia Region) & 2016 & $6-11$ & 562 & 0.2 & 63.3 & $0.90(0.92)$ & $1.6(1.8)$ & $85.2(95.2)$ & Present study \\
\hline \multirow{3}{*}{ BPF } & Japan (Hokkaido) & $2012-2017$ & 7 & 396 & 0.02 & 83 & - & 0.07 & - & {$[44]$} \\
\hline & South Korea & $2017-2018$ & $7-12$ & 286 & $0.19^{* * *}$ & 9.4 & - & $<0.19$ & 0.54 & {$[46]$} \\
\hline & Spain (Valencia Region) & 2016 & $6-11$ & 562 & 0.2 & 11.6 & $<0.2$ & $<0.2$ & $3.2(2.6)$ & Present study \\
\hline \multirow{4}{*}{ BPS } & Japan (Hokkaido) & $2012-2017$ & 7 & 396 & 0.04 & 78 & - & 0.11 & - & [44] \\
\hline & USA & $2013-2016$ & $6-11$ & 965 & 0.1 & - & 0.36 & - & - & [45] \\
\hline & South Korea & 2017-2018 & $7-12$ & 286 & $0.13^{* * *}$ & 75.2 & 0.23 & 0.21 & 1.1 & [46] \\
\hline & Spain (Valencia Region) & 2016 & $6-11$ & 562 & 0.2 & 28.6 & $<0.2$ & $<0.2$ & $6.8(6.1)$ & Present study \\
\hline \multirow{3}{*}{ MP } & Canada & $2016-2017$ & $6-11$ & 540 & $1.3^{*}$ & 88.4 & 7.5 & 4.9 & - & [42] \\
\hline & South Korea & 2015-2017 & $6-11$ & 839 & - & - & - & 18.1 & - & [48] \\
\hline & Spain (Valencia Region) & 2016 & $6-11$ & 562 & 0.2 & 62.3 & $1.4(1.4)$ & $2.4(2.5)$ & $541.4(574.4)$ & Present study \\
\hline \multirow{4}{*}{ EP } & Canada & 2016-2017 & $6-11$ & 540 & $0.9^{*}$ & 26.3 & - & $<0.9$ & - & [42] \\
\hline & South Korea & 2015-2017 & $6-11$ & 839 & - & - & - & 10.4 & - & [48] \\
\hline & Germany & $2014-2017$ & $3-17$ & 516 & 0.5 & 69 & 0.943 & 0.73 & 12.0 & [49] \\
\hline & Spain (Valencia Region) & 2016 & $6-11$ & 562 & 0.2 & 48.4 & $<0.2$ & $<0.2$ & $18.0(21.0)$ & Present study \\
\hline \multirow{4}{*}{ PP } & Canada & $2016-2017$ & $6-11$ & 540 & $0.3^{*}$ & 70.3 & 0.96 & 0.69 & - & {$[42]$} \\
\hline & South Korea & 2015-2017 & $6-11$ & 839 & - & - & - & 1.3 & - & [48] \\
\hline & Germany & 2014-2017 & $3-17$ & 516 & 0.5 & 31 & 0.563 & $<0.5$ & 18.5 & [49] \\
\hline & Spain (Valencia Region) & 2016 & $6-11$ & 562 & 0.2 & 59.6 & $0.39(0.40)$ & $0.40(0.41)$ & $61.3(61.3)$ & Present study \\
\hline \multirow{3}{*}{ BP } & Canada & $2016-2017$ & $6-11$ & 540 & $0.3^{*}$ & 7.2 & - & $<0.3$ & $<0.3$ & [42] \\
\hline & Germany & 2014-2017 & $3-17$ & 516 & 0.5 & 2 & $<0.5$ & $<0.5$ & $<0.5$ & [49] \\
\hline & Spain (Valencia Region) & 2016 & $6-11$ & 562 & 0.2 & 21.5 & $<0.2$ & $<0.2$ & $7.3(9.1)$ & Present study \\
\hline
\end{tabular}


Table 5. Cont.

\begin{tabular}{|c|c|c|c|c|c|c|c|c|c|c|}
\hline Analyte & Country (City or Region) & Year SAMPLING & $\begin{array}{c}\text { Age } \\
\text { (Years) }\end{array}$ & $\begin{array}{l}\text { Sample } \\
\text { Size }\end{array}$ & $\begin{array}{c}\text { LOQ } \\
\text { (ng/mL) }\end{array}$ & $\mathrm{DF} \%$ & $\begin{array}{l}\text { GM ng/mL } \\
\text { ( } \mu \mathrm{g} / \mathrm{g} \text { Creat) }\end{array}$ & $\begin{array}{c}\text { Median ng/mL } \\
(\mu \mathrm{g} / \mathrm{g} \text { Creat })\end{array}$ & $\begin{array}{l}\text { P95 ng/mL } \\
\text { ( } \mu \text { g/g Creat) }\end{array}$ & Reference \\
\hline \multirow{7}{*}{ МEHP } & Iran (Isfahan) & 2016 & $6-18$ & 242 & - & 99.6 & 59.09 & 61.27 & - & [50] \\
\hline & Canada & $2016-2017$ & $6-11$ & 534 & $0.11 *$ & 99.9 & 1.4 & 1.4 & 5.8 & {$[42]$} \\
\hline & USA & 2015-2016 & $6-11$ & 415 & 0.8 & - & 1.42 & 1.30 & 5.9 & [52] \\
\hline & Czech Republic & 2016 & 5 and 9 & 370 & 2 & 62.4 & 2.3 & - & 7.3 & [53] \\
\hline & Germany & 2015-2017 & 6-10 & 736 & 0.5 & 86 & 1.4 & 1.5 & 6.8 & [54] \\
\hline & Italy & 2015-2017 & $4-14$ & 900 & 0.58 & 99.3 & 9.26 & 8.90 & 23.48 & [55] \\
\hline & Spain (Valencia Region) & 2016 & $5-12$ & 557 & 1 & 84.6 & $3.6(3.6)$ & $3.7(3.8)$ & $24.0(25.2)$ & Present study \\
\hline \multirow{8}{*}{ МЕОНР } & Iran (Isfahan) & 2016 & $6-18$ & 242 & - & 95.9 & 178.72 & 270.92 & - & {$[50]$} \\
\hline & Canada & 2016-2017 & $6-11$ & 537 & $0.17 *$ & 100 & 7.0 & 7.5 & 31 & [42] \\
\hline & Europe ${ }^{* * * *}$ & 2013-2016 & $6-12$ & 1300 & $0.12-0.5$ * & 99.9 & - & $(12.5)$ & - & [51] \\
\hline & South Korea & 2015-2017 & $6-11$ & 839 & - & - & - & 19.7 & - & [48] \\
\hline & USA & 2015-2016 & 6-11 & 415 & 0.2 & - & 5.97 & 6.1 & 24.5 & [52] \\
\hline & Czech Republic & 2016 & 5 and 9 & 370 & 2 & 98.6 & 12.9 & - & 41.3 & [53] \\
\hline & Germany & 2015-2017 & $6-10$ & 736 & 0.2 & 100 & 9 & 9 & 32.1 & [54] \\
\hline & Spain (Valencia Region) & 2016 & $5-12$ & 555 & 0.5 & 100.0 & $9.1(9.2)$ & $9.3(9.2)$ & $37.9(34.2)$ & Present study \\
\hline \multirow{3}{*}{ 2сxMMHP } & Canada & 2016-2017 & $6-11$ & 537 & $0.27 *$ & 98.8 & 3.1 & 3.1 & 13 & [42] \\
\hline & China (Shenzhen) & 2016-2017 & $6-8$ & 1490 & 0.2 & 100 & (7.96) & $(7.59)$ & $(36.5)$ & [56] \\
\hline & Spain (Valencia Region) & 2016 & $5-12$ & 557 & 2 & 77.9 & $4.0(4.1)$ & $4.0(4.1)$ & $18.5(19.5)$ & Present study \\
\hline \multirow{7}{*}{ МЕСРP } & Canada & 2016-2017 & $6-11$ & 535 & $0.28 *$ & 100 & 13 & 13 & 52 & [42] \\
\hline & Europe ${ }^{* * * *}$ & 2013-2016 & $6-12$ & 1300 & - & 99.9 & - & $(35.1)$ & - & [51] \\
\hline & South Korea & 2015-2017 & $6-11$ & 839 & - & - & - & 44.9 & - & [48] \\
\hline & USA & 2015-2016 & $6-11$ & 415 & 0.4 & - & 14.6 & 14.9 & 60.3 & [52] \\
\hline & Germany & 2015-2017 & $6-10$ & 736 & 0.2 & 100 & 14.1 & 13.8 & 47.7 & {$[54]$} \\
\hline & China (Shenzhen) & $2016-2017$ & $6-8$ & 1490 & 0.1 & 100 & $(19.8)$ & (20.3) & $(78.0)$ & [56] \\
\hline & Spain (Valencia Region) & 2016 & $5-12$ & 557 & 1 & 100.0 & $27.0(27.5)$ & $27.9(29.1)$ & $101.0(90.5)$ & Present study \\
\hline
\end{tabular}


Table 5. Cont.

\begin{tabular}{|c|c|c|c|c|c|c|c|c|c|c|}
\hline Analyte & Country (City or Region) & Year SAMPLING & $\begin{array}{c}\text { Age } \\
\text { (Years) }\end{array}$ & $\begin{array}{c}\text { Sample } \\
\text { Size }\end{array}$ & $\begin{array}{c}\text { LOQ } \\
(\mathrm{ng} / \mathrm{mL})\end{array}$ & $\mathrm{DF} \%$ & $\begin{array}{l}\text { GM ng/mL } \\
\text { ( } \mu \mathrm{g} / \mathrm{g} \text { Creat) }\end{array}$ & $\begin{array}{c}\text { Median ng/mL } \\
(\mu \mathrm{g} / \mathrm{g} \text { Creat })\end{array}$ & $\begin{array}{l}\text { P95 ng/mL } \\
\text { ( } \mu g / g \text { Creat) }\end{array}$ & Reference \\
\hline \multirow{8}{*}{ МЕHНP } & Iran (Isfahan) & 2016 & $6-18$ & 242 & - & 96.3 & 114.20 & 177.56 & - & {$[50]$} \\
\hline & Canada & 2016-2017 & $6-11$ & 537 & $0.22 *$ & 100 & 9.7 & 9.9 & 44 & [42] \\
\hline & South Korea & 2015-2017 & $6-11$ & 839 & - & - & - & 30.2 & - & [48] \\
\hline & USA & 2015-2016 & 6-11 & 415 & 0.4 & - & 8.81 & 9.0 & 39.0 & {$[52]$} \\
\hline & Czech Republic & 2016 & 5 and 9 & 370 & 1.5 & 100 & 20.6 & - & 66.3 & [53] \\
\hline & Germany & 2015-2017 & 6-10 & 736 & 0.2 & 100 & 12.7 & 12.9 & 43.6 & [54] \\
\hline & China (Shenzhen) & 2016-2017 & $6-8$ & 1490 & 0.3 & 100 & $(23.1)$ & $(22.2)$ & $(85.7)$ & {$[56]$} \\
\hline & Spain (Valencia Region) & 2016 & $5-12$ & 557 & 2 & 98.7 & $11.9(12.1)$ & $11.9(11.4)$ & $53.1(48.3)$ & Present study \\
\hline \multirow{6}{*}{ MEP } & Canada & 2016-2017 & $6-11$ & 536 & $0.98 *$ & 99.5 & 18 & 15 & - & [42] \\
\hline & Europe ${ }^{* * * *}$ & 2013-2016 & $6-12$ & 1301 & $0.15-1 *$ & 100 & - & $(33.5)$ & - & [51] \\
\hline & USA & 2015-2016 & $6-11$ & 415 & 1.2 & - & 24.5 & 22.1 & 211 & [52] \\
\hline & Germany & 2015-2017 & $6-10$ & 736 & 0.5 & 100 & 21.7 & 19.8 & 165 & [54] \\
\hline & China (Shenzhen) & 2016-2017 & $6-8$ & 1490 & 0.3 & 98 & $(14.3)$ & $(13.8)$ & (142) & {$[56]$} \\
\hline & Spain (Valencia Region) & 2016 & $5-12$ & 557 & 2 & 99.8 & $55.0(55.9)$ & $51.1(53.2)$ & $498.0(405.4)$ & Present study \\
\hline \multirow{9}{*}{ MnBP } & Canada & 2016-2017 & $6-11$ & 536 & $0.6^{*}$ & 100 & 20 & 19 & 84 & {$[42]$} \\
\hline & Europe ${ }^{* * * *}$ & 2013-2016 & $6-12$ & 1301 & $0.15-1 *$ & 100 & - & $(23.9)$ & - & [51] \\
\hline & South Korea & 2015-2017 & $6-11$ & 839 & - & - & - & 45.0 & - & [48] \\
\hline & USA & 2015-2016 & 6-11 & 415 & 0.4 & - & 14.4 & 15.4 & 47.2 & [52] \\
\hline & Czech Republic & 2016 & 5 and 9 & 370 & 1.6 & 100 & 63.0 & - & 233.0 & [53] \\
\hline & Germany & 2015-2017 & $6-10$ & 736 & 1 & 100 & 22.9 & 22.5 & 80.2 & {$[54]$} \\
\hline & Thailand (Bangkok) & 2016 & $2-18$ & 221 & - & 88.6 & $(214.4)$ & $(252)$ & - & [57] \\
\hline & China (Shenzhen) & 2016-2017 & $6-8$ & 1490 & 0.1 & 99 & (185) & (212) & $(832)$ & {$[56]$} \\
\hline & Spain (Valencia Region) & 2016 & $5-12$ & 557 & 0.5 & 99.6 & $14.0(14.2)$ & $13.8(13.6)$ & $51.5(58.6)$ & Present study \\
\hline \multirow{7}{*}{ MiBP } & Canada & 2016-2017 & $6-11$ & 536 & $0.57 *$ & 99.9 & 15 & 14 & 74 & {$[42]$} \\
\hline & Europe ${ }^{* * * *}$ & 2013-2016 & $6-12$ & 1301 & $0.15-0.5$ * & 100 & - & $(41.8)$ & - & [51] \\
\hline & USA & 2015-2016 & 6-11 & 415 & 0.8 & - & 11.2 & 11.6 & 59.7 & [52] \\
\hline & Czech Republic & 2016 & 5 and 9 & 370 & 2.7 & 100 & 44.1 & - & 233.6 & [53] \\
\hline & Germany & 2015-2017 & $6-10$ & 736 & 1 & - & $(27.1)$ & $(24.7)$ & $(97.9)$ & {$[54]$} \\
\hline & China (Shenzhen) & 2016-2017 & $6-8$ & 1490 & 1.5 & 94 & (32.1) & $(36.8)$ & (176) & [56] \\
\hline & Spain (Valencia Region) & 2016 & $5-12$ & 557 & 2 & 98.6 & $18.4(18.7)$ & $18.4(17.6)$ & $83.2(85.4)$ & Present study \\
\hline
\end{tabular}


Table 5. Cont.

\begin{tabular}{|c|c|c|c|c|c|c|c|c|c|c|}
\hline Analyte & Country (City or Region) & Year SAMPLING & $\begin{array}{l}\text { Age } \\
\text { (Years) }\end{array}$ & $\begin{array}{l}\text { Sample } \\
\text { Size }\end{array}$ & $\begin{array}{c}\text { LOQ } \\
\text { (ng/mL) }\end{array}$ & $\mathrm{DF} \%$ & $\begin{array}{c}\text { GM ng/mL } \\
\text { ( } \mu \mathrm{g} / \mathrm{g} \text { Creat) }\end{array}$ & $\begin{array}{c}\text { Median ng/mL } \\
(\mu \mathrm{g} / \mathrm{g} \text { Creat })\end{array}$ & $\begin{array}{c}\text { P95 ng/mL } \\
\text { ( } \mu \mathrm{g} / \mathrm{g} \text { Creat) }\end{array}$ & Reference \\
\hline \multirow{8}{*}{ MBzP } & Iran (Isfahan) & 2016 & $6-18$ & 242 & - & 100 & 173.17 & 240.77 & - & [50] \\
\hline & Canada & 2016-2017 & $6-11$ & 537 & $0.37 *$ & 99.4 & 10 & 9.6 & 58 & [42] \\
\hline & Europe ${ }^{* * * *}$ & $2013-2016$ & $6-12$ & 1300 & $0.06-0.5$ * & 99.9 & - & $(5.0)$ & - & [51] \\
\hline & South Korea & 2015-2017 & $6-11$ & 839 & - & - & - & 3.3 & - & [48] \\
\hline & USA & 2015-2016 & $6-11$ & 415 & 0.3 & - & 10.7 & 10.9 & 81.1 & [52] \\
\hline & Czech Republic & 2016 & 5 and 9 & 370 & 1.9 & 71.6 & 3.7 & - & 32.9 & [53] \\
\hline & Germany & 2015-2017 & $6-10$ & 736 & 0.2 & 100 & 3.4 & 3.2 & 19 & [54] \\
\hline & Spain (Valencia Region) & 2016 & $5-12$ & 557 & 1 & 88.2 & $3.0(3.0)$ & $2.8(2.9)$ & $17.8(19.5)$ & Present study \\
\hline
\end{tabular}

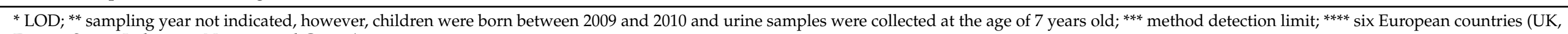
France, Spain, Lithuania, Norway and Greece). 
Regarding parabens, in all studies, the MP was the compound most frequently detected and showed the highest concentrations, while BP showed the lowest detection frequencies and concentrations. In comparison with the present study, the rest of the studies showed higher levels of DF for all parabens except BP, which in the present study had the highest DF (21.5\%).

With reference to phthalates, the DFs were high (80-100\%) in most of the studies, and DEHP metabolites levels were similar or higher in studies developed in Iran, Italy, South Korea, China, Europe and Czech Republic. Only the studies developed in Canada, USA and Germany showed lower levels of DEHP metabolites than in the present study. Regarding biomarkers of short-chain phthalates, all studies showed lower levels of MEP (metabolite of DEP), however, the levels of DnBP, DiBP and BzBP biomarkers (MnBP, MiBP and MBzP, respectively) were similar or higher in the rest of studies in comparison with the present study, and only the study developed in China showed lower levels of MBzP.

Table S4 shows the levels of bisphenols, parabens and phthalates urinary biomarkers in studies involving Children in Spain. As can be seen, BPA was previously studied in children from Sabadell, Granada, Madrid and Añover de Tajo [58-60]. The BPA DFs were $>90 \%$ in all the previous studies, however in our study, the DF\% was lower (63\%). Furthermore, the GMs in previous studies were in a range from 1.87 to $5.8 \mu \mathrm{g} / \mathrm{g}$ creatinine, while in our study the GM was much lower $(0.92 \mu \mathrm{g} / \mathrm{g}$ creatinine). As far as we know, the levels of BPF and BPS have not been previously studied in Spanish children.

Regarding parabens, Casas et al. [61] studied the urinary levels of MP, EP, PP and BP in children from Granada, and despite their LOD being equal or lower than in our study, the DF\% were higher (80-100\%) than in our study (21-62\%). Furthermore, the levels in the Granada children were also much higher, with medians ranging from 1.2 to $150 \mathrm{ng} / \mathrm{mL}$, while in the Valencian children the median range was $<0.2$ to $2.4 \mathrm{ng} / \mathrm{mL}$. On the other hand, both in Valencian and Granada children the parabens with the highest DFs and concentration were MP and PP.

Urinary phthalate metabolites were studied in children from Madrid, Añover de Tajo and Granada $[60,61]$. The DFs of phthalate metabolites were slightly higher in previous studies, and the concentrations were much higher, especially in Añover de Tajo, with GMs ranging from 7.5 to $259.8 \mu \mathrm{g} / \mathrm{g}$ creatinine, while in Valencian children the GMs ranged from 3.0 to $55.9 \mu \mathrm{g} / \mathrm{g}$ creatinine. The present study was the largest study implemented in Spanish children, with more than 500 samples, while the other studies had 19 to 172 participants.

The fact that the Valencian study showed lower levels of DFs could be related to the year of sampling, since in previous studies the samples were collected between 2005 and 2012, while in the Valencian study the samples were collected in 2016. The reduction in the use of these products and the substitution with analogues, such as BPF and BPS in the case of BPA, or DINCH in the case of phthalates, could explain this reduction.

With reference to the predictor study, we have not found an explanation to the negative association between BPA levels in urine and the consumption of eggs, canned fish and processed fish. It should be expected that a higher consumption of canned food would be related with a higher exposure to BPA, since BPA is present in the epoxy resins used to internally coat the cans [2]. On the other hand, BPA levels were positively associated with consumption of white fish and drinks. Gys et al. [62] studied the levels of bisphenols in Flemish adolescents and also found a relation between BPA levels in urine and consumption of local fish. Martinez et al. [63] observed that the reduction of canned drinks during pregnancy in women from Spain was related with lower levels of BPA in urine. Regarding parabens, girls had significatively higher levels of PP than boys. This fact could be related to a higher exposition to parabens through the use of personal care products. However, we cannot confirm this hypothesis, since we do not have data of cosmetic use. A lower adherence to a Mediterranean diet was associated with higher levels of EP and MEP (metabolite of DEP). However, Ax et al. [64] studied the correlation between Mediterranean diet and phthalate levels in blood, and did not find significant correlations. EP can be used as a food additive as a preservative, therefore, it is possible that people with a higher 
adherence to a Mediterranean diet consume less food containing additives. Children with higher consumption of molluscs showed higher levels of metabolites of BzBP and DEHP, and children with higher consumption of small white fish showed higher levels of the biomarker of DEP. Sánchez-Ávila et al., [65] detected levels of DEHP in mussels from three out of five coastal and estuarine sites studied in the Cantabrian Sea (Spain). Furthermore, Castro-Jiménez \& Ratola [66] detected levels of DEHP in both wild and commercial mussels, levels of BzBP in wild mussels and levels of DEP in fish from the Mediterranean Sea. Furthermore, boys showed higher urinary levels of MEHP (DEHP metabolite) than girls from the present study, however, we have not found an explanation for this association.

The risk assessment study showed that the internal exposure of the Valencian children to BPA, MP, EP and DEP, DnBP, BzBP and DINP is of low concern, using the guidance values as a reference. However, emerging data show that exposure to low levels of these contaminants can be associated with adverse outcomes [67]. Furthermore, some oxidized DINP metabolites as mono(hydroxyl-isononyl) phthalate and mono(oxo-isononyl) phthalate [68] should be studied in future studies, in order to assess the internal exposure to DINP. Furthermore, some oxidized metabolites of BP have been described and detected in urine, and could improve the biomonitoring of this paraben in the future [26].

\section{Conclusions}

This is the largest biomonitoring study of urinary biomarkers of phthalates, bisphenols and parabens in Spanish children. Despite the children being widely exposed to these chemicals, the detection frequencies and levels were lower than in other studies involving children in other regions of Spain, and were lower, in general, than recent studies developed in other countries. The risk assessment study concluded that the internal exposure to these emerging chemicals is of low concern for the Valencian children. The future study of other oxidized metabolites of phthalates and parabens will improve the assessment of the internal exposure of these compounds.

Supplementary Materials: The following are available online at https:/ /www.mdpi.com/article/10 $.3390 /$ ijerph18178909/s1. Figure S1. Histograms of Log-concentration of urinary phthalate metabolites; Table S1: Frequency of food consumption by groups in the population (grams/month); Table S2: Bisphenols parabens and phthalates and their urine biomarkers determined in the present study and their respective parents; Table S3: Biomonitoring equivalents (BE) and HBM I guidance values for BPA and phthalates in urine; Table S4: Urinary biomarker levels of bisphenols, parabens and phthalates in Spanish children.

Author Contributions: P.D., Risk assessment and writing manuscript; N.L., sample analysis; Y.S., sample analysis; F.C.-B., statistics; S.F.F., risk assessment; C.S.H., risk assessment; G.S., creatinine analysis and review of manuscript; E.P.-Z., creatinine analysis, A.M.-H., creatinine analysis; O.P., review of manuscript; C.C., review of manuscript; A.L., review of manuscript; V.Y., project administration, review of manuscript and supervision. All authors have read and agreed to the published version of the manuscript.

Funding: This study was supported by the GV /2019/137 project funded by the Generalitat Valenciana. Pablo Dualde acknowledges his "Ayudas para la contratación PTA" (PTA2018-016320-I) from “Ministerio de Ciencia e Innovación" (Spain).

Institutional Review Board Statement: The BIOVAL study and the sampling protocol had been approved by the Scientific Ethics Committee of the Valencian Research Centre for Public Health (FISABIO).

Informed Consent Statement: Informed consent was obtained from all parents or guardians of all children involved in the study.

Data Availability Statement: The children data used to support the findings of this study are restricted in order to protect their privacy. Data are available from Vicent Yusà, yusa_vic@gva.es, for researchers who meet the criteria for access to confidential data. 
Acknowledgments: The BIOVAL study is part of the Food Contaminants Exposure and Risk Assessment Program of the Valencian Community (Spain). The authors are grateful to all the BIOVAL Task Force (BIOVAL team of the public health centers), including the food safety inspectors participating in sample collection, and also to the IBSPCV BioBank (PT13/0010/0064) integrated in the Spanish National Biobank Network and the Valencian Biobanking Network for their collaboration. Our thanks to Joan Quiles for his contribution to design the food surveys, to Petra S. Fišerová for her manuscript revision and comments and to the families and children who kindly volunteered to participate in the study.

Conflicts of Interest: The authors declare no conflict of interest.

\section{References}

1. Landrigan, P.; Fuller, R.; Acosta, N.J.R.; Adeyi, O.; Arnold, R.; Basu, N.; Baldé, A.B.; Bertollini, R.; Bose-O’Reilly, S.; Boufford, J.I.; et al. The Lancet Commission on Pollution and Health. Lancet 2018, 391, 462-512. [CrossRef]

2. Mercogliano, R.; Santonicola, S. Investigation on Bisphenol A Levels in Human Milk and Dairy Supply Chain: A Review. Food Chem. Toxicol. 2018, 114, 98-107. [CrossRef]

3. Geens, T.; Aerts, D.; Berthot, C.; Bourguignon, J.; Goeyens, L.; Lecomte, P.; Maghuin-Rogister, G.; Pironnet, A.; Pussemier, L.; Scippo, M.; et al. A Review of Dietary and Non-Dietary Exposure to Bisphenol-A. Food Chem. Toxicol. 2012, 50, 3725-3740. [CrossRef]

4. Chen, D.; Kannan, K.; Tan, H.; Zheng, Z.; Feng, Y.; Wu, Y.; Widelka, M. Bisphenol Analogues Other than BPA: Environmental Occurrence, Human Exposure, and Toxicity-A Review. Environ. Sci. Technol. 2016, 50, 5438-5453. [CrossRef]

5. WHO. Joint FAO/WHO Expert Meeting to Review Toxicological and Health Aspects of Bisphenol A: Final Report, Including Report of Stakeholder Meeting on Bisphenol A, 1-5 November 2010, Ottawa, ON, Canada. Available online: http:/ / whqlibdoc. who.int/publications/2011/97892141564274_eng.pdf (accessed on 20 November 2017).

6. EFSA. Scientific Opinion on the risks to public health related to the presence of bisphenol A (BPA) in foodstuffs. EFSA J. 2015, 13, 3978. [CrossRef]

7. Wittassek, M.; Koch, H.M.; Angerer, J.; Bruening, T. Assessing Exposure to Phthalates-the Human Biomonitoring Approach. Mol. Nutr. Food Res. 2011, 55, 7-31. [CrossRef]

8. Commission Directive 2007/19/EC of 30 March 2007 Amending Directive 2002/72/EC Relating to Plastic Materials and Articles Intended to Come into Contact with Food and Council Directive 85/572/EEC Laying down the List of Simulants to be Used for Testing Migration of Constituents of Plastic Materials and Articles Intended to Come into Contact with Foodstuffs. Available online: https: / / eur-lex.europa.eu/legal-content/ES/TXT/?uri=CELEX:32007L0019R(02) (accessed on 23 June 2021).

9. Regulation (EC) No 1907/2006 of the European Parliament and of the Council of 18 December 2006 Concerning the Registration, Evaluation, Authorisation and Restriction of Chemicals (REACH), establishing a European Chemicals Agency, Amending Directive 1999/45/EC and Repealing Council Regulation (EEC) No 793/93 and Commission Regulation (EC) No 1488/94 as well as Council Directive 76/769/EEC and Commission Directives 91/155/EEC, 93/67/EEC, 93/105/EC and 2000/21/EC. Available online: https: / / eur-lex.europa.eu/legal-content/EN/TXT/?uri=CELEX\%3A02006R1907-20140410 (accessed on 23 June 2021).

10. Regulation (EC) No 1223/2009 of the European Parliament and of the Council of 30 November 2009 on Cosmetic Products. Available online: https:/ / ec.europa.eu/health/sites/default/files/endocrine_disruptors/docs/cosmetic_1223_2009_regulation_ en.pdf (accessed on 21 June 2021).

11. EMA, 2014. Guideline on the Use of Phthalates as Excipients in Human Medicinal Products. European Medicines Agency 20 November 2014. EMA/CHMP/SWP/362974/2012 Corr 2. Committee for Medicinal Products for Human Use (CHMP). Available online: https:/ / www.ema.europa.eu/en/documents/scientific-guideline/guideline-use-phthalates-excipients-humanmedicinal-products_en.pdf (accessed on 12 April 2020).

12. Directive 2007/47/EC of the European Parliament and of the Council of 5 September 2007 Amending Council Directive 90/385/EEC on the Approximation of the Laws of the Member States Relating to Active Implantable Medical Devices, Council Directive 93/42/EEC Concerning Medical Devices and Directive 98/8/EC Concerning the Placing of Biocidal Products on the Market. Available online: https:/ / eur-lex.europa.eu/legal-content/EN/ALL/?uri=celex:32007L0047 (accessed on 19 June 2021).

13. Heudorf, U.; Mersch-Sundermann, V.; Angerer, J. Phthalates: Toxicology and Exposure. Int. J. Hyg. Environ. Health 2007, 210, 623-634. [CrossRef] [PubMed]

14. Ejaredar, M.; Nyanza, E.C.; Ten Eycke, K.; Dewey, D. Phthalate Exposure and Childrens Neurodevelopment: A Systematic Review. Environ. Res. 2015, 142, 51-60. [CrossRef]

15. Bledzka, D.; Gromadzinska, J.; Wasowicz, W. Parabens. from Environmental Studies to Human Health. Environ. Int. 2014, 67, 27-42. [CrossRef] [PubMed]

16. Nowak, K.; Ratajczak-Wrona, W.; Gorska, M.; Jablonska, E. Parabens and their Effects on the Endocrine System. Mol. Cell. Endocrinol. 2018, 474, 238-251. [CrossRef] 
17. EU Directive (2006), 2006/52/EC OF THE EUROPEAN PARLIAMENT AND OF THE COUNCIL of 5 July 2006 Amending Directive 95/2/EC on Food Additives Other Than Colours and Sweeteners and Directive 94/35/EC on Sweeteners for Use in Foodstuffs. Available online: https:/ / eur-lex.europa.eu/legal-content/EN/TXT/?uri=CELEX:32006L0052R(01) (accessed on 18 June 2021).

18. SANTE, 2017. European Commission, SANTE-2017-11668 Medicines Revision 2, VOLUME 2C. Guidelines Medicinal Products for Human Use Safety, Environment and Information. Excipients in the Labelling and Package Leaflet of Medicinal Products for Human Use. Brussels, March 2018. Available online: https:/ / ec.europa.eu/health/sites/default/files/files/eudralex/vol-2/c/ guidelines_excipients_march2018_en.pdf (accessed on 18 June 2021).

19. EU Cosmetic Legislation. Available online: https:/ / ec.europa.eu/growth/sectors/cosmetics/legislation_en (accessed on 19 June 2021).

20. Carmona, E.; Andreu, V.; Pico, Y. Occurrence of Acidic Pharmaceuticals and Personal Care Products in Tuna River Basin: From Waste to Drinking Water. Sci. Total. Environ. 2014, 484, 53-63. [CrossRef]

21. Ahn, H.; An, B.; Jung, E.; Yang, H.; Choi, K.; Jeung, E. Parabens Inhibit the Early Phase of Folliculogenesis and Steroidogenesis in the Ovaries of Neonatal Rats. Mol. Reprod. Dev. 2012, 79, 626-636. [CrossRef]

22. Guerra, M.T.; Sanabria, M.; Leite, G.A.A.; Borges, C.S.; Cucielo, M.S.; Anselmo-Franci, J.A.; Foster, W.G.; Kempinas, W.G. Maternal Exposure to Butyl Paraben Impairs Testicular Structure and Sperm Quality on Male Rats. Environ. Toxicol. 2017, 32, 1273-1289. [CrossRef]

23. Kang, K.; Che, J.; Ryu, D.; Kim, T.; Li, G.; Lee, Y. Decreased Sperm Number and Motile Activity on the F1 Offspring Maternally Exposed to Butyl p-Hydroxybenzoic Acid (Butyl Paraben). J. Vet. Med. Sci. 2002, 64, 227-235. [CrossRef]

24. EFSA. Opinion of the Scientific Panel on Food Additives, Flavourings, Processing Aids and Materials in Contact with Food on a Request from the Commission related to para hydroxybenzoates (E 214-219) Question number EFSA-Q-2004-063 (adopted on 13 July 2004). EFSA J. 2004, 2, 83.

25. Volkel, W.; Bittner, N.; Dekant, W. Quantitation of Bisphenol A and Bisphenol A Glucuronide in Biological Samples by High Performance Liquid Chromatography-Tandem Mass Spectrometry. Drug Metab. Dispos. 2005, 33, 1748-1757. [CrossRef] [PubMed]

26. Moos, R.K.; Angerer, J.; Dierkes, G.; Bruening, T.; Koch, H.M. Metabolism and Elimination of Methyl, Iso- and n-Butyl Paraben in Human Urine after Single Oral Dosage. Arch. Toxicol. 2016, 90, 2699-2709. [CrossRef]

27. Frederiksen, H.; Skakkebaek, N.E.; Andersson, A. Metabolism of Phthalates in Humans. Mol. Nutr. Food Res. 2007, 51, 899-911. [CrossRef] [PubMed]

28. HBM4EU. Available online: https:/ / www.hbm4eu.eu/ (accessed on 15 February 2015).

29. GerES-V 2015. Information of the study German Environmental Survey for Children and Adolescents GerES 2014-2017. Available online: https://www.umweltbundesamt.de/sites/default/files/medien/355/dokumente/geresv_study_information_public_ eng_1.pdf (accessed on 15 June 2020).

30. Perez, R.; Domenech, E.; Coscolla, C.; Yusa, V. Human Biomonitoring of Food Contaminants in Spanish Children: Design, Sampling and Lessons Learned. Int. J. Hyg. Environ. Health 2017, 220, 1242-1251. [CrossRef]

31. Sanchis, Y.; Coscolla, C.; Yusa, V. Analysis of Four Parabens and Bisphenols A, F, S in Urine, using Dilute and Shoot and Liquid Chromatography Coupled to Mass Spectrometry. Talanta 2019, 202, 42-50. [CrossRef]

32. Dualde, P.; Leon, N.; Pardo, O.; Coscolla, C.; Vento, M.; Pastor, A.; Yusa, V. BETTERMILK Project. Risk Assessment of Exposure to Phthalates in Breastfeeding Women using Human Biomonitoring. Chemosphere 2020, 255, 127003. [CrossRef] [PubMed]

33. SANTE/12682/2019. Analytical Quality Control and Method Validation Procedures for Pesticide Residues Analysis in Food and Feed. Available online: https:/ / ec.europa.eu/food/system/files/2020-01/pesticides_mrl_guidelines_wrkdoc_2019-12682.pdf (accessed on 21 June 2021).

34. Barr, D.; Wilder, L.; Caudill, S.; Gonzalez, A.; Needham, L.; Pirkle, J. Urinary Creatinine Concentrations in the US Population: Implications for Urinary Biologic Monitoring Measurements. Environ. Health Perspect. 2005, 113, 192-200. [CrossRef] [PubMed]

35. EFSA. European Food Safety Authority; Management of left-censored data in dietary exposure assessment of chemical substances. EFSA J. 2010, 8, 96. Available online: www.efsa.europa.eu (accessed on 18 June 2021). [CrossRef]

36. Gelman, A. Scaling Regression Inputs by Dividing by Two Standard Deviations. Stat. Med. 2008, 27, 2865-2873. [CrossRef]

37. Konishi, S.; Kitagawa, G. Information Criteria and Statistical Modeling. In Information Criteria and Statistical Modeling; Springer: New York, NY, USA, 2008; pp. 1-273.

38. Maronna, R.A.; Martin, R.D.; Yohai, V.J.; Salibián-Barrera, M. Robust Statistics: Theory and Methods (with R), 2nd ed.; Springer: Berlin/Heidelberg, Germany, 2018.

39. Steckling, N.; Gotti, A.; Bose-O’Reilly, S.; Chapizanis, D.; Costopoulou, D.; De Vocht, F.; Gari, M.; Grimalt, J.O.; Heath, E.; Hiscock, R.; et al. Biomarkers of Exposure in Environment-Wide Association Studies-Opportunities to Decode the Exposome using Human Biomonitoring Data. Environ. Res. 2018, 164, 597-624. [CrossRef]

40. Katsikantami, I.; Colosio, C.; Alegakis, A.; Tzatzarakis, M.N.; Vakonaki, E.; Rizos, A.K.; Sarigiannis, D.A.; Tsatsakis, A.M. Estimation of Daily Intake and Risk Assessment of Organophosphorus Pesticides Based on Biomonitoring Data-the Internal Exposure Approach. Food Chem. Toxicol. 2019, 123, 57-71. [CrossRef] [PubMed]

41. Remer, T.; Fonleyn, N.; Ute, A.Y.; Yer, S.B. Longitudinal Examination of 24-h Urinary Iodine Excretion in Schoolchildren as a Sensitive, Hydration Status-Independent Research Tool for Studying Iodine Status. Am. J. Clin. Nutr. 2006, 83, 639-646. [CrossRef] [PubMed] 
42. Health Canada, 2019. Fifth Report on Human Biomonitoring on Environmental Chemicals in Canada. Available online: https:/ / www.canada.ca/en/health-canada/services/environmental-workplace-health/reports-publications/environmentalcontaminants / fifth-report-human-biomonitoring.html (accessed on 15 June 2021).

43. Guo, J.; Zhang, J.; Wu, C.; Xiao, H.; Lv, S.; Lu, D.; Qi, X.; Feng, C.; Liang, W.; Chang, X.; et al. Urinary Bisphenol A Concentrations and Adiposity Measures at Age 7 Years in a Prospective Birth Cohort. Chemosphere 2020, 251, 126340. [CrossRef]

44. Gys, C.; Bamai, Y.A.; Araki, A.; Bastiaensen, M.; Caballero-Casero, N.; Kishi, R.; Covaci, A. Biomonitoring and Temporal Trends of Bisphenols Exposure in Japanese School Children. Environ. Res. 2020, 191, 110172. [CrossRef]

45. Jacobson, M.H.; Woodward, M.; Bao, W.; Liu, B.; Trasande, L. Urinary Bisphenols and Obesity Prevalence among U.S. Children and Adolescents. J. Endocr. Soc. 2019, 3, 1715-1726. [CrossRef]

46. Jo, M.J.; Park, J.; An, K.; Choi, H.; Kang, Y.; Hwang, M. Quantification of Bisphenols in Korean Urine using Online Solid-Phase Extraction-High-Performance Liquid Chromatography-Tandem Mass Spectrometry. Environ. Toxicol. Pharmacol. 2020, 80, 103491. [CrossRef]

47. Li, Y.; Zhang, H.; Kuang, H.; Fan, R.; Cha, C.; Li, G.; Luo, Z.; Pang, Q. Relationship between Bisphenol a Exposure and Attentiondeficit/hyperactivity Disorder: A Case-Control Study for Primary School Children in Guangzhou, China. Environ. Pollut. 2018, 235, 141-149. [CrossRef]

48. Lim, S. The Associations between Personal Care Products use and Urinary Concentrations of Phthalates, Parabens, and Triclosan in various Age Groups: The Korean National Environmental Health Survey Cycle 3 2015-2017. Sci. Total. Environ. 2020, 742, 140640. [CrossRef]

49. Murawski, A.; Tschersich, C.; Rucic, E.; Schwedler, G.; Moos, R.K.; Kasper-Sonnenberg, M.; Bruning, T.; Koch, H.M.; KolossaGehring, M. Parabens in Urine of Children and Adolescents in Germany-Human Biomonitoring Results of the German Environmental Survey 2014-2017 (GerES V). Environ. Res. 2021, 194, 110502. [CrossRef]

50. Amin, M.M.; Ebrahimpour, K.; Parastar, S.; Shoshtari-Yeganeh, B.; Hashemi, M.; Mansourian, M.; Poursafa, P.; Fallah, Z.; Rafiei, N.; Kelishadi, R. Association of Urinary Concentrations of Phthalate Metabolites with Cardiometabolic Risk Factors and Obesity in Children and Adolescents. Chemosphere 2018, 211, 547-556. [CrossRef]

51. Haug, L.S.; Sakhi, A.K.; Cequier, E.; Casas, M.; Maitre, L.; Basagana, X.; Andrusaityte, S.; Chalkiadaki, G.; Chatzi, L.; Coen, M.; et al. In-Utero and Childhood Chemical Exposome in Six European Mother-Child Cohorts. Environ. Int. 2018, 121, 751-763. [CrossRef] [PubMed]

52. NHANES, 2019. Fourth National Report on Human Exposure to Environmental Chemicals. Updated Tables, January 2019, Volume One. Available online: https:/ / www.cdc.gov/ exposurereport/index.html (accessed on 15 June 2021).

53. Puklova, V.; Janos, T.; Sochorova, L.; Vavrous, A.; Vrbik, K.; Fialova, A.; Hanzlikova, L.; Cerna, M. Exposure to Mixed Phthalates in Czech Preschool and School Children. Arch. Environ. Contam. Toxicol. 2019, 77, 471-479. [CrossRef] [PubMed]

54. Schwedler, G.; Rucic, E.; Lange, R.; Conrad, A.; Koch, H.M.; Paelmke, C.; Bruening, T.; Schulz, C.; Schmied-Tobies, M.I.H.; Daniels, A.; et al. Phthalate Metabolites in Urine of Children and Adolescents in Germany. Human Biomonitoring Results of the German Environmental Survey GerES V, 2014-2017. Int. J. Hyg. Environ. Health 2020, 225, 113444. [CrossRef]

55. Tait, S.; Carli, F.; Busani, L.; Buzzigoli, E.; Della Latta, V.; Deodati, A.; Fabbrizi, E.; Gaggini, M.; Maranghi, F.; Tassinari, R.; et al. Biomonitoring of Bis(2-Ethylhexyl)Phthalate (DEHP) in Italian Children and Adolescents: Data from LIFE PERSUADED Project. Environ. Res. 2020, 185, 109428. [CrossRef]

56. Yao, Y.; Chen, D.; Wu, Y.; Zhou, L.; Cheng, J.; Ma, Y.; Lu, S.; Yuan, G.; Liu, G. Urinary Phthalate Metabolites in Primary School Starters in Pearl River Delta, China: Occurrences, Risks and Possible Sources. Environ. Res. 2019, 179, 108853. [CrossRef] [PubMed]

57. Sedtasiriphokin, N.; Supornsilchai, V.; Jantarat, C.; Nosoongnoen, W. Phthalate Exposure in Thai Children and Adolescents. Asian Biomed. 2017, 11, 343-351. [CrossRef]

58. Casas, M.; Valvi, D.; Luque, N.; Ballesteros-Gomez, A.; Carsin, A.; Fernandez, M.F.; Koch, H.M.; Mendez, M.A.; Sunyer, J.; Rubio, S.; et al. Dietary and Sociodemographic Determinants of Bisphenol A Urine Concentrations in Pregnant Women and Children. Environ. Int. 2013, 56, 10-18. [CrossRef] [PubMed]

59. Mustieles, V.; Ocon-Hernandez, O.; Minguez-Alarcon, L.; Davila-Arias, C.; Perez-Lobato, R.; Calvente, I.; Arrebola, J.P.; Vela-Soria, F.; Rubio, S.; Hauser, R.; et al. Bisphenol A and Reproductive Hormones and Cortisol in Peripubertal Boys: The INMA-Granada Cohort. Sci. Total. Environ. 2018, 618, 1046-1053. [CrossRef]

60. Cutanda, F.; Koch, H.M.; Esteban, M.; Sanchez, J.; Angerer, J.; Castano, A. Urinary Levels of Eight Phthalate Metabolites and Bisphenol A in Mother-Child Pairs from Two Spanish Locations. Int. J. Hyg. Environ. Health 2015, 218, 47-57. [CrossRef]

61. Casas, L.; Fernandez, M.F.; Llop, S.; Guxens, M.; Ballester, F.; Olea, N.; Basterrechea Irurzun, M.; Santa Marina Rodriguez, L.; Riano, I.; Tardon, A.; et al. Urinary Concentrations of Phthalates and Phenols in a Population of Spanish Pregnant Women and Children. Environ. Int. 2011, 37, 858-866. [CrossRef]

62. Gys, C.; Bastiaensen, M.; Bruckers, L.; Colles, A.; Govarts, E.; Martin, L.R.; Verheyen, V.; Koppen, G.; Morrens, B.; Den Hond, E.; et al. Determinants of Exposure Levels of Bisphenols in Flemish Adolescents. Environ. Res. 2021, 193, 110567. [CrossRef]

63. Martinez, M.A.; Gonzalez, N.; Marti, A.; Marques, M.; Rovira, J.; Kumar, V.; Nadal, M. Human Biomonitoring of Bisphenol a Along Pregnancy: An Exposure Reconstruction of the EXHES-Spain Cohort. Environ. Res. 2021, 196, 110941. [CrossRef] [PubMed]

64. Ax, E.; Lampa, E.; Lind, L.; Salihovic, S.; van Bavel, B.; Cederholm, T.; Sjogren, P.; Lind, P.M. Circulating Levels of Environmental Contaminants are Associated with Dietary Patterns in Older Adults. Environ. Int. 2015, 75, 93-102. [CrossRef] 
65. Sanchez-Avila, J.; Vicente, J.; Echavarri-Erasun, B.; Porte, C.; Tauler, R.; Lacorte, S. Sources, Fluxes and Risk of Organic Micropollutants to the Cantabrian Sea (Spain). Mar. Pollut. Bull. 2013, 72, 119-132. [CrossRef]

66. Castro-Jimenez, J.; Ratola, N. An Innovative Approach for the Simultaneous Quantitative Screening of Organic Plastic Additives in Complex Matrices in Marine Coastal Areas. Environ. Sci. Pollut. Res. 2020, 27, 11450-11457. [CrossRef]

67. Mustieles, V.; Fernández, M.F. Bisphenol A shapes children's brain and behavior: Towards an integrated neurotoxicity assessment including human data. Environ. Health 2020, 19, 66. [CrossRef]

68. Hays, S.M.; Aylward, L.L.; Kirman, C.R.; Krishnan, K.; Nong, A. Biomonitoring Equivalents for Di-Isononyl Phthalate (DINP). Regul. Toxicol. Pharmacol. 2011, 60, 181-188. [CrossRef] 